\title{
AN OPTIMAL TWO-STAGE ALLOCATION OF MATERIAL FLOWS IN A TRANSPORT-LOGISTIC SYSTEM WITH CONTINUOUSLY DISTRIBUTED RESOURCE
}

Us S. A. - PhD, Professor of the Department of System Analysis and Control, National TU Dnipro Polytechnic, Ukraine.

Koriashkina L. S. - PhD, Associate Professor of the Department of System Analysis and Control, National TU Dnipro Polytechnic, Ukraine.

Stanina O. D. - Assistant of the Department of Computer Information Technologies of the Ukrainian State Chemistry and Technology University, Ukraine.

\begin{abstract}
Context. The object of the research is a two-stage process of material flows allocation in the transport-logistic system, the structural elements of which are enterprises that collect a resource, is been distributed in a certain territory (centers of the first stage), and the enterprises that consume or process this resource. A mathematical model of such process is a two-stage problem of the optimal partitioning of a continual set with the locating of subset centers under additional constraints presented in the paper.

Objective. The goal of the work is to ensure the reduction of transport costs in the organization of multi-stage production, the raw material resource of which is distributed in some territory, through the development of appropriate mathematical apparatus and software. The urgency of the work is explained by one of the most pronounced tendencies in extracting and processing branches of industry and agriculture, namely, the creation of territorially-distributed multilevel companies that include dozens of large enterprises and carry out a full cycle of production from raw material harvesting with its integrated use and the product manufacturing to its transportation to end consumers.

Method. Mathematical apparatus for two-stage problems of optimal partitioning of sets with additional couplings was developed using the basic concepts of the theory of continuous linear problems of optimal set partitioning, duality theory, and methods for solving linear programming problems of transport type. The research shows that the formulation of a multi-stage transport-logistic problem in a continuous variant (in the form of an infinite-dimensional optimization problem) is expedient when the number of resource suppliers is limited but very large. The application of the developed mathematical apparatus makes it possible to find the optimal solution of the two-stage allocation-distribution problem in an analytic form (the analytic expression includes parameters that are the optimal solution of the auxiliary finite-dimensional optimization problem with a nondifferentiable objective function). The proposed iterative algorithm for solving the formulated problem bases on modification of Shor's r-algorithm and the method of potentials for solving the transport problem.

Results. Developed mathematical models, methods and algorithms for solving continuous multi-stage problems for locating enterprises with a continuously distributed resource can be used to solve a wide class of continuous linear location-allocation problems. The presented methods, algorithms and software allow solving several practical problems connected, for example, with the strategic planning in the production, social and economic fields. The theoretical results obtained are been brought to the level of specific recommendations that can be used by state-owned and private enterprises in solving logistics tasks related to the organization of collection of a certain resource and its delivery to processing points, as well as further transportation of the product received to places of destination.

Conclusions. The results of the computational experiments testify to the correctness of the developed algorithms operation for solving two-stage optimal set partitioning problems with additional couplings. Furthermore, it is confirmed the feasibility of formulating such problems when it is necessary to determine the location of new objects in a given territory, considering the multistage raw material resource distribution process. Further research is subject to the theoretical justification of the convergence of the iterative process realized in the proposed algorithm for solving continuous problems of OPS with additional couplings. In future, the development of software to solve such problems with the involvement of GIS-technologies is planned.
\end{abstract}

KEYWORDS: multi-stage transport and logistics systems, continuously distributed resource, optimal partitioning of sets, continuous location-allocation problems.

\author{
ABBREVIATIONS \\ OPS - optimal partitioning of sets; \\ OPSAC - optimal partitioning of sets with additional \\ couplings.
}

\section{NOMENCLATURE}

$\Omega-$ area on which the resource is distributed, and where the first-stage centers can be located;

$\rho(x)$ - resource reservoir in each point $x$ of $\Omega$ area;

$N$ - number of first-stage centers;

$M$ - number of second-stage centers;
$S$ - total quantity of resource in a given area;

$\tau_{i}^{r}$ - coordinates of $r$-stage $i$-center;

$b_{i}^{r}$ - cardinality of $r$-stage $i$-center, $r=I, I I$;

$c_{i}^{I}\left(x, \tau_{i}^{I}\right)$ - resource unit delivery cost from point $x \in \Omega$ to center $\tau_{i}^{I}$;

$c_{i j}^{I I}\left(\tau_{i}^{I}, \tau_{j}^{I I}\right)-$ unit delivery cost from center $\tau_{i}^{I}$ to center $\tau_{j}^{I I}$;

(C) Us S. A., Koriashkina L. S., Stanina O. D., 2019

DOI 10.15588/1607-3274-2019-1-24 
$a_{i}-$ resource sorting and shipment cost in the enterprise $\tau_{i}^{I}$, calculated per resource unit;

$v_{i j}$ - resource amount delivered from the center $\tau_{i}^{I}$ to center $\tau_{j}^{I I}$;

$R_{N M}^{+} \quad N M-$ dimensional space of nonnegative real numbers;

$\Sigma_{\Omega}^{N}$ - class of all possible partitions of the set $\Omega$ into $N$ disjoint subsets;

$\bar{\omega}=\left\{\Omega_{1}, \ldots, \Omega_{N}\right\}-$ Element of class $\Sigma_{\Omega}^{N}$;

$\lambda_{i}(\cdot)$ - characteristic functions of the subsets $\Omega_{i}$, $i=1, \ldots, N$;

$F(\cdot)$ - functional of SPPAC;

$\psi_{i}-$ dual variable (potential of center $\tau_{i}^{I}$ ), $i=1, \ldots, N$;

$\eta_{j}-$ dual variable (potential of center $\left.\tau_{j}^{I I}\right), j=1, \ldots, M$.

\section{INTRODUCTION}

Transport-logistic systems, functionality of which includes the material resources circulation processes, are quite capacious and complex. Such systems are characterized by many economic agents and intermediaries located in different regions and large areas, differences in quantity of customer demands, many other factors that predetermine the specifics of the organization of the movement of material resources.

In the modern economic region (country) development conditions, these processes are carried out not only within the framework of one independent enterprise, but also outside, in other similar structures located in different places of the considered region, that determines their multi-stage of logistics processes.

The object of study is a two-stage material flows allocation process in a transport-logistic system, the structural elements of which are enterprises that collect a certain continuously distributed on a given territory resource (hereinafter centers of the first stage), and enterprises that consume or process this resource (centers of the second stage). In such systems, each center of the first stage, as a rule, is assigned to the territory (zone) of its servicing. The movement of material flows is carried out first in the direction from each point of the considered area directly to the enterprise servicing it, and then the primary processed or sorted resource is sent in certain quantities to the enterprises acting as consumers of this resource. Examples of such logistic processes and related optimization tasks are:

- rational collection of agricultural crops and their delivery first to the granaries, and then to the end user;

- forming a network of modern waste transfer stations and waste sorting stations to reduce the specific total costs for the export of waste;

(C) Us S. A., Koriashkina L. S., Stanina O. D., 2019

DOI 10.15588/1607-3274-2019-1-24
- planning of logging operations and subsequent removal of timber with the organization of intermediate warehouses, taking into account not only the specific plots being developed, but also the possibility of using pile sites for delivering timber to them from neighboring felling areas;

- distribution of materials flows between customers, points of receipt and processing of raw materials, ensuring minimum transportation costs;

- formation of a regional warehouse network, net of a postal delivery services.

The subject of study is mathematical models and theoretical justification of methods and algorithms for solving multi-stage transport problems with a resource that is continuously distributed in a given territory (occupied a certain area).

The purpose of the work is to ensure the reduction of transportation costs in the organization of multi-stage production, the raw material resource of which is continuously distributed in some territory.

\section{PROBLEM STATEMENT}

Here is the most general formulation of the two-stage continuous location-allocation problem, which arises in the organization of a two-stage transport and logistics system (Fig. 1) and which called the set partitioning problem with additional constraints (SPPAC). It is necessary to find the location coordinates of the first-stage centers in a given territory, determine the service areas of these centers for the collection of raw materials and distribute the preliminary sorted raw materials between the centers of the second stage minimizing total transport costs.

Problem A. To find such partition of set $\Omega$ into disjoint subsets $\bar{\omega}=\left\{\Omega_{1}, \Omega_{2}, \ldots, \Omega_{N}\right\}$ (some of which can be empty), to determine coordinates of its centers $\tau_{1}^{I}, \ldots, \tau_{N}^{I}$ and supply volumes $v_{11}, \ldots, v_{N M}$, under which the functional

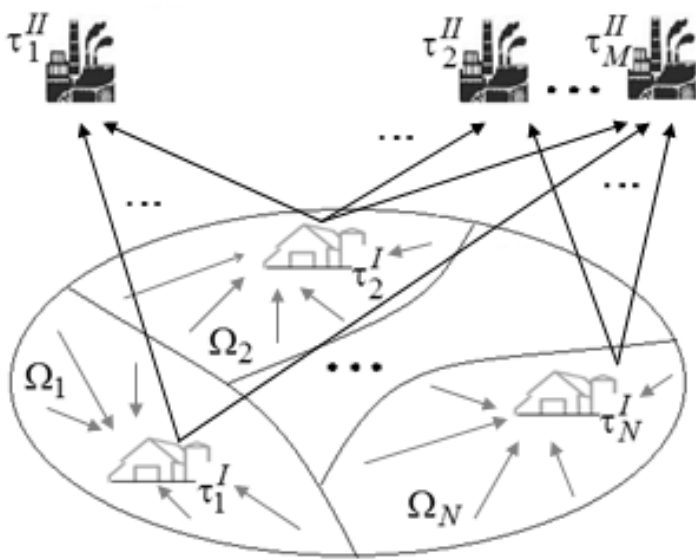

Figure 1 - Scheme of material flows distribution in the twostage continuous optimal location - allocation problem 


$$
\begin{gathered}
F\left(\bar{\omega}, \tau^{I}, v\right)=\sum_{i=1}^{N} \int_{\Omega_{i}} c_{i}^{I}\left(x, \tau_{i}^{I}\right) \rho(x) d x+ \\
+\sum_{i=1}^{N} \sum_{j=1}^{M}\left(c_{i j}^{I I}\left(\tau_{i}^{I}, \tau_{j}^{I I}\right)+a_{i}\right) v_{i j}
\end{gathered}
$$

would have reached a minimum value, and the following conditions were satisfied:

$$
\begin{gathered}
\int_{\Omega_{i}} \rho(x) d x=\sum_{j=1}^{M} v_{i j}, i=\overline{1, N}, \\
\sum_{i=1}^{N} v_{i j}=b_{j}^{I I}, j=\overline{1, M}, \\
\bar{\omega} \in \Sigma_{\Omega}^{N}, v \in R_{N M}^{+}, \tau^{I} \in \Omega^{N}, \\
\Sigma_{\Omega}^{N}=\left\{\bar{\omega}=\left\{\Omega_{1}, \ldots, \Omega_{N}\right\}: \bigcup_{i=1}^{N} \Omega_{i}=\Omega, \operatorname{mes}\left(\Omega_{i} \cap \Omega_{j}\right)=0,\right. \\
i \neq j, i, j=\overline{1, L}\} .
\end{gathered}
$$

Comment. In the case where the centers are known in advance, we formulate a continuous problem of optimal partitioning of the set for fixed centers of subsets (or a continuous problem of OPS with additional constraints):

Promlem A1. Find $F(\bar{\omega}, v) \rightarrow$ min under conditions (2) $-(5)$.

\section{REVIEW OF THE LITERATURE}

System studies related to the construction of efficient algorithms for solving multi-stage location/allocation problems were carried out at different times by domestic, in particular [1-9], and by foreign scientists, for example [10-24].

A mathematical model of the problem of minimizing transportation costs, storage costs and grain losses presented in [1], considers the two-stage scheme of grain transportation from the combine to the elevator.

The model of forming a system of two-stage transportation of solid municipal waste, proposed in [2] allows obtaining information on the optimal location and number of waste transfer stations. Economic and mathematical models for solving multi-stage transportproduction problems of planning and management of material flows between timber enterprises were described in [3]. Vertically integrated production structures of the timber industry complex, variants of their use in the practice of enterprises, are considered.

In [4] the two-stage problem of placing production on a tree network are considered. It is provided that the costs of transporting a product unit from point to point are equal to the sum of the lengths of the edges in the chain connecting these points. An algorithm for exact solving this problem has a laboriousness $O\left(\mathrm{~nm}^{3}\right)$, where $n$ - the number of points of demand for the final product, $m-$ the (C) Us S. A., Koriashkina L. S., Stanina O. D., 2019 DOI 10.15588/1607-3274-2019-1-24 maximum number of possible locations for the production of each stage.

Properties of the problem of enterprises location with indivisible consumers with non-decreasing nonlinear functions of production costs were studied in [5]. In the same place, the rules for rejecting non-optimal solutions are formulated and proved. An algorithm for solving the discrete programming problem combining the ideas of the approximation-combinatorial method and the branch and boundary method was developed.

The problem of distributing goods from one or several factories through warehouses with expected projected volumes of customer needs and possible overlapping of service areas for warehouses is presented in [10]. Here, a multistage problem of stochastic programming with regression and a method for solving it are formulated. The problem of distribution planning is considered with the planning horizon in the N-stages, when the stage is defined as the period during which the client's requirements are realized, and decisions must be made before the following requirements are met.

In [11], the authors note to support the efficient operation of complex production and transportation systems, such parameters as cost, availability, product quality and delivery should be both priority. An important scientific research direction in a strategic perspective, the authors emphasize the development of analytical and simulation models that combine the main stages of the supply chain. In the supply chain presented in [12], the product life cycle, predictability of demand, product versatility and market standards for preparation and output are considered. Such a model makes it possible to ascertain the nature of demand for products, and on this basis to organize the supply of products to the best meet demand.

In [13], the problem of mixed integer programming was formulated to solve the problem of two-stage distribution planning, in which: 1) various goods can be provided to customers from a number of enterprises, through a series of intermediate warehouses; 2) for each given possible location of the warehouse, there is a fixed cost of opening the corresponding warehouse, operating costs and maximum throughput; 3) it is known the demand of each customer for each product, the cost of shipping from the factory to a possible warehouse, and then to the customer; 4) it is required to select the locations for the opening warehouses and to create a delivery schedule in such a way that the total cost has been minimized. To solve the problem, the authors applied the method of branches and boundaries

In [14], consider the design of multiproduct, multiechelon supply chain networks. The networks comprise a number of manufacturing sites at fixed locations, a number of warehouses and distribution centers of unknown locations (to be selected from a set of potential locations), and finally a number of customer zones at fixed locations. The system is mathematically modeled as mixed-integer linear programming optimization problem, the solution of which should determine the number, 
location and capacity of warehouses and distribution centers, transport links that need to be installed in the network, and the flows and rates of production of materials. The criterion of optimization is the minimization of the total annual cost of the network, taking into account both the infrastructure and operating costs.

The importance of accounting the inherent trade costs of equipment, inventory, transportation costs and "responsiveness" of customers when identifying the location of distribution centers in the development of logistics systems also emphasizes in [15]. An approach such modeling that provides integrated view are illustrated in the context of a specific example related to the distribution of cars produced by a car concern.

The paper [16] contains a broad review of current scientific publications devoted to the design of a distribution system. The formulation of the allocationdistribution problems presented here varies in complexity from simple linear, single-stage, single-product, deterministic to non-linear/probabilistic models. Algorithms, including, among other things, local search and mixed integer programming, are evaluated in terms of computational complexity and performance. Also, a wide range of practical applications is presented.

The paper [17] is devoted to the study of optimal planning of multi-stage production and distribution networks, including the location of factories and distribution centers under specific restrictions. The formulated NP-complete problem takes into account the three stages of resource allocation in the network and is a more accurate abstraction of the real world, because prices and transport costs for raw materials can vary significantly among suppliers, depending on their location, other factors that need to be considered. Since the mixed-integer model contains many variables, the authors proposed a methodology for solving it using the genetic algorithm.

Problems of the development of effective heuristic algorithms for solving partially integer mathematical programming problems, which are models of optimal multi-stage distribution networks, are also considered in $[18,19]$.

Interesting from the point of practical application view is the paper [20], which deals with the design of a supply chain network with so-called "pop-up" stores that can be opened for several weeks or months before the season closes on the market. The supply chain network is designed for a company that is one of the producers of vegetable oils in Turkey and includes a warehouse located between suppliers and factories for storing materials, as well as pop-up stores open between plants and customers. The proposed model is multi-period and multistage with three quality criteria under restrictions on resource stocks. The first criterion is to minimize the transportation costs at all stages. The second goal is to minimize the cost of creating pop-up stores. The third quality criterion is to minimize inventory costs and extra-budgetary expenses. Also, as in many of the above works, the mixed integer (C) Us S. A., Koriashkina L. S., Stanina O. D., 2019 DOI 10.15588/1607-3274-2019-1-24 linear programming problem with a vector criterion is formulated and solved here.

To solve the problem of designing a logistics system with a multi-stage structure, taking into account production/distribution planning, a genetic algorithm with fuzzy logic elements was developed in [21] to manage its parameters. The unification of concepts and the description of multi-stage transport systems, as well as their integration in supply chain management systems, is proposed [22].

In [23], a comprehensive review of scientific research conducted over the last 40 years in modeling and solving the problem of locating objects in a multi-tier network has been given to effectively serve clients both at the lowest hierarchy level (to minimize costs) and on the highest level of the hierarchy (to maximize the availability of services). The hierarchical models published here are classified based on such characteristics as the type of the flow pattern, the availability of services, the spatial configuration, the objective function, the coverage, the network levels, the availability of the time element, the capacity, etc. In addition, a classification of methods for solving such problems and real practical applications is given.

Two-stage problems of locating objects with limited powers are considered in [24].

In contrast to all the above papers, in $[9,25,26]$, when formulating multi-stage location-allocation problems, it is assumed that the initial resource densely occupies a certain area. In this case, mathematical models acquire a continuous character and are infinite-dimensional programming problems. The continuity of the problem formulated in this paper is also due to the possibility of locating the first stage centers at any point of a given area. The paper devotes to the research and development of methods and algorithms for solving precisely such problems.

\section{MATERIALS AND METHODS}

We assume that for the problem $(1)-(5)$ the condition

$$
\sum_{j=1}^{M} b_{j}^{I I}=\int_{\Omega} \rho(x) d x
$$

are fulfilled. Under (6) the set of all possible partitions (that satisfying the conditions (2), (3)) is no empty.

According to the theory of continuous linear optimal set partitioning problems [27] we introduce the following characteristic functions of the subsets $\Omega_{i}$ :

$$
\lambda_{i}(x)=\left\{\begin{array}{l}
1, x \in \Omega_{i}, \\
0, x \in \Omega \backslash \Omega_{i}, \quad i=1, \ldots, N,
\end{array}\right.
$$

and rewrite Problem A as the infinite-dimensional mathematical programming problem with Boolean variables in the following form. 
Problem B. Find

$$
\min _{\left(\lambda(\cdot), \tau^{N}, v\right) \in \Gamma \times \Omega^{N} \times R_{N M}^{+}} I\left(\lambda(\cdot), \tau^{N}, \nu\right),
$$

where

$$
\begin{gathered}
I\left(\lambda(\cdot), \tau^{N}, v\right)=\sum_{i=1}^{N} \int_{\Omega} c_{i}^{I}\left(x, \tau_{i}^{I}\right) \rho(x) \lambda_{i}(x) d x+ \\
+\sum_{i=1}^{N} \sum_{j=1}^{M}\left(c_{i j}^{I I}\left(\tau_{i}^{I}, \tau_{j}^{I I}\right)+a_{i}\right) v_{i j},
\end{gathered}
$$

under the condition

$$
\begin{gathered}
\sum_{i=1}^{N} v_{i j}=b_{j}^{I I}, j=1,2, \ldots, M, \\
\sum_{j=1}^{M} v_{i j}=\int_{\Omega} \rho(x) \lambda_{i}(x) d x, i=1,2, \ldots, N, \\
\Gamma=\left\{\lambda(x)=\lambda_{1}(x), \ldots, \lambda_{N}(x)\right): \\
\lambda_{i}(x)=0 \vee 1, i=\overline{1, N}, \text { a.e. for } x \in \Omega, \\
\left.\sum_{i=1}^{N} \lambda_{i}(x)=1 \text { a.e. for } x \in \Omega\right\} .
\end{gathered}
$$

Further we insert the set $\Gamma$ into the following simplex $\Gamma_{0}=\left\{\lambda(x)=\lambda_{1}(x), \ldots, \lambda_{N}(x)\right)$ :

$$
\begin{aligned}
& 0 \leq \lambda_{i}(x) \leq 1, i=\overline{1, N}, \text { a.e. for } x \in \Omega, \\
& \left.\sum_{i=1}^{N} \lambda_{i}(x)=1 \text { a.e. for } x \in \Omega\right\},
\end{aligned}
$$

and pass from the Problem $\mathbf{B}$ to the problem with the values of $\lambda_{i}(\cdot)$ from $[0 ; 1], i=\overline{1, N}$ :

Задача C. Find

$$
\begin{gathered}
\min _{\left(\lambda(\cdot), \tau^{N}, v\right) \in \Gamma_{0} \times \Omega^{N} \times R_{N M}^{+}} I\left(\lambda(\cdot), \tau^{N}, v\right), \\
I\left(\lambda(\cdot), \tau^{N}, v\right)=\sum_{i=1}^{N} \int_{\Omega} c_{i}^{I}\left(x, \tau_{i}^{I}\right) \rho(x) \lambda_{i}(x) d x+ \\
+\sum_{i=1}^{N} \sum_{j=1}^{M}\left(c_{i j}^{I I}\left(\tau_{i}^{I}, \tau_{j}^{I I}\right)+a_{i}\right) v_{i j}, \\
\sum_{i=1}^{N} v_{i j}=b_{j}^{I I}, j=1,2, \ldots, M, \\
\sum_{j=1}^{M} v_{i j}=\int_{\Omega} \rho(x) \lambda_{i}(x) d x, i=1,2, \ldots, N .
\end{gathered}
$$

The set of optimal solutions of Problem $C$ contains the optimal solutions of Problem B, and hence the solving of Problem B reduces to the solving of Problem $\mathrm{C}$ and to the selecting from all its optimal solutions the one that are also solutions of Problem B.

Applying the apparatus of the duality theory for problem $\mathrm{C}$ and taking into account the equivalence of problems $\mathrm{A}$ and $\mathrm{B}$, it is proved that for every fixed vector $\tau \in \Omega^{N}$ and each vector $\nu \in R_{N M}^{+}$the following theorems take place (analogous to theorems for continuous OPS problems under constraints from [29]).

Theorem 1. Let in problem $\mathbf{A}$ the function $\rho(x) \geq 0$ a.e. for $x \in \Omega$, the parameters $b_{1}^{I I}, \ldots, b_{M}^{I I}$ satisfy the condition (6). In order that a possible partition $\left(\Omega_{*_{1}}, \ldots, \Omega_{*_{i}}, \ldots, \Omega_{*_{N}}\right) \in \Sigma_{\Omega}^{N}$ of the set $\Omega$ be optimal for Problem A, it is necessary and sufficient that there exist real constants $\psi_{1}, \psi_{2}, \ldots, \psi_{N}$ such that

$$
c_{i}^{I}\left(x, \tau_{i}^{I}\right)+\psi_{i} \leq c_{j}^{I}\left(x, \tau_{j}^{I}\right)+\psi_{j}
$$

$i \neq j$, a.e. for $x \in \Omega_{*_{i}}, i, j=1, \ldots N$

Corollary 1. If the conditions of Theorem 1 hold for Problem A, at points $x$, belonging to the optimal boundary of subsets $\Omega *_{i}$ and $\Omega_{*_{j}}$, the equality sign is attained in inequality (7).

Theorem 2. Let function $\rho(x) \geq 0$ a.e. for $x \in \Omega$, and condition (6) is satisfied. Then triple $\left\{\lambda^{*}(\cdot), \tau^{I^{*}}, v^{*}\right\} \in \Gamma_{0} \times \Omega^{N} \times R_{N M}^{+}$is an optimal solution of the problem $\mathrm{C}$ if and only if there are real constants $\psi_{i}^{*}, i=1, \ldots, N$, and $\eta_{j}^{*}, j=1, \ldots, M$, under which for $i=1, \ldots, N$ and almost all $x \in \Omega$

$\lambda_{*_{i}}(x)=\left\{\begin{aligned} 1, \text { if } c_{i}^{I}\left(x, \tau_{*_{i}}^{I}\right)+\psi_{i}^{*} \leq c_{j}^{I}\left(x, \tau_{*_{j}}^{I}\right)+\psi_{j}^{*}, \\ \quad i \neq j \text { a.e. for } x \in \Omega, j=1, \ldots, N, \text { then } x \in \Omega_{*_{i}}, \\ 0 \text { in the other cases. }\end{aligned}\right.$ In the capacity of $\tau_{*_{i}}^{I}, \psi_{i}^{*}, i=1, \ldots, N$ and $\eta_{j}^{*}, j=1, \ldots, M$ the optimal solution to the problem

$$
G(\psi, \eta) \rightarrow \max , \psi \in R^{N}, \eta \in R^{M},
$$

where

$$
\begin{gathered}
G(\psi, \eta)=\min _{\left\{\tau^{I}, v\right\} \in \Omega^{N} \times R_{N M}^{+}} G_{1}\left(\left\{\tau^{I}, v\right\}, \psi, \eta\right), \\
G_{1}\left(\left\{\tau^{I}, v\right\}, \psi, \eta\right)=\int_{\Omega} \min _{k}\left(c_{k}^{I}\left(x, \tau_{k}^{I}\right)+\psi k\right) \rho(x) d x+ \\
+\sum_{i=1}^{N} \sum_{j=1}^{M}\left(c_{i j}^{I I}\left(\tau_{i}^{I}, \tau_{j}^{I I}\right)+a_{i}-\eta_{j}-\psi_{i}\right) v_{i j}+\sum_{j=1}^{M} \eta_{j} b_{j}^{I I} .
\end{gathered}
$$

If in the problem $\mathbf{A}$ the first stage centers $\tau_{1}^{I}, \ldots, \tau_{N}^{I}$ are given, it is proved, that the necessary and sufficient condition for the optimality of the pair 
$\left\{\lambda^{*}(\cdot), v^{*}\right\} \in \Gamma_{0} \times R_{N M}^{+}$in conforming problem $\mathrm{B}$ is existence of such real constants $\psi_{i}^{*}, i=1, \ldots, N$, and $\eta_{j}^{*}, j=1, \ldots, M$, under which the following conditions are satisfied:

1) for all $i=1, \ldots, N$ and almost all $x \in \Omega$

$$
\lambda_{*_{i}}(x)=\left\{\begin{array}{l}
1, \text { if } c_{i}^{I}\left(x, \tau_{i}^{I}\right)+\psi_{i}^{*}= \\
\quad=\min _{m=1, N}\left(c_{m}^{I}\left(x, \tau_{m}^{I}\right)+\psi_{m}^{*}\right), \\
0 \text { in the other cases, } i=1, \ldots, N ;
\end{array}\right.
$$

2) for all $i=1, \ldots, N$ and $j=1, \ldots, M$

$$
\left\{\begin{array}{l}
c_{i j}^{I I}\left(\tau_{i}^{I}, \tau_{j}^{I I}\right)+a_{i}=\psi_{i}^{*}+\eta_{j}^{*}, \text { if } v_{i j}^{*}>0, \\
c_{i j}^{I I}\left(\tau_{i}^{I}, \tau_{j}^{I I}\right)+a_{i}>\psi_{i}^{*}+\eta_{j}^{*}, \text { if } v_{i j}^{*}=0 .
\end{array}\right.
$$

In [28] the iteration algorithm for solving problem A1 (with given coordinates of centers) is presented. It is developed on the ground of formulas (9) and (10) under the assumption that $\rho(x) \geq 0$ for all $x \in \Omega$. We give its version with a refinement of the initial approximation choosing. Here, at the beginning we assign to each first stage center the points $x \in \Omega$, lying at the shortest distance from it. Without loss of generality, we consider that the set is a parallelepiped whose sides are parallel to the axes of the Cartesian rectangular coordinate system.

\section{Algorithm 1.}

Initialization. specify the computational errors $\varepsilon_{1}>0$, $\varepsilon_{2}>0$

Let $k=0$

Specify the initial approximation of the characteristic functions of subsets $\Omega_{i}, i=\overline{1, N}$, as follows:

$$
\lambda_{i}^{(0)}(x)=\left\{\begin{array}{c}
1, \text { if } c_{i}^{I}\left(x, \tau_{i}^{I}\right)= \\
\quad=\min _{m=1, N} c_{m}^{I}\left(x, \tau_{m}^{I}\right), \\
0 \text { in the other cases, } i=1, \ldots, N .
\end{array}\right.
$$

Compute values $b_{i}^{I(k)}$ by formulas:

$$
b_{i}^{I(k)}=\int_{\Omega} \rho(x) \lambda_{i}^{(k)}(x) d x, i=\overline{1, N} .
$$

Define values $v_{i j}^{(k)}, \quad \psi_{i}^{(k)} \eta_{j}^{(k)}, \quad i=\overline{1, N}, j=\overline{1, M}$, solving the following linear programming problem of the transport type:

$$
\sum_{i=1}^{N} \sum_{j=1}^{M} c_{i j}^{I I}\left(\tau_{i}^{I}, \tau_{j}^{I I}\right) v_{i j} \rightarrow \min
$$

$$
\begin{gathered}
\sum_{j=1}^{M} v_{i j}=b_{i}^{I(k)}, i=1,2, \ldots, N, \\
\sum_{i=1}^{N} v_{i j}=b_{j}^{I I}, j=1,2, \ldots, M, \\
v_{i j} \geq 0, i=1,2, \ldots, N, j=1,2, \ldots, M .
\end{gathered}
$$

Let, as a result of performing $k, k=0,1,2, \ldots$ steps of the algorithm, definite values of the components of vector-function $\lambda^{(k)}(x)$ in each point $x \in \Omega$ and current approximation of parameters $\psi_{i}^{(k)}, \eta_{j}^{(k)}, v_{i j}^{(k)}, i=\overline{1, N}$, $j=\overline{1, M}$ are obtained.

Perform the $(k+1)$ th step as follows:

1. Compute $\lambda_{i}^{k+1}(x)$ by formulas:

$$
\lambda_{i}^{(k+1)}(x)=\left\{\begin{array}{l}
1, \text { if } c_{i}^{I}\left(x, \tau_{i}^{I}\right)+\psi_{i}^{(k)}= \\
\quad=\min _{m=1, N}\left(c_{m}^{I}\left(x, \tau_{m}^{I}\right)+\psi_{m}^{(k)}\right), \\
0 \text { in the other cases, } i=1, \ldots, N .
\end{array}\right.
$$

2. Compute the values $b_{i}^{I(k+1)}$ by formulas:

$$
b_{i}^{I(k+1)}=\int_{\Omega} \rho(x) \lambda_{i}^{(k+1)} d x, i=\overline{1, N} .
$$

3. Define the values $v_{i j}^{(k+1)}, \psi_{i}^{(k+1)} \eta_{j}^{(k+1)}, i=\overline{1, N}$, $j=\overline{1, M}$, solving the following linear programming problem of the transport type (11)-(14).

4. Compute the value of the objective functional

$$
\begin{aligned}
I(\lambda(\cdot), v)= & \sum_{i=1}^{N} \int_{\Omega} c_{i}^{I}\left(x, \tau_{i}^{I}\right) \rho(x) \lambda_{i}(x) d x+ \\
& +\sum_{i=1}^{N} \sum_{j=1}^{M}\left(c_{i j}^{I I}\left(\tau_{i}^{I}, \tau_{j}^{I I}\right)+a_{i}\right) v_{i j}
\end{aligned}
$$

under $\lambda_{i}(x)=\lambda_{i}^{(k+1)}(x), v_{i j}=v_{i j}^{(k+1)}, i=\overline{1, N}, j=\overline{1, M}$.

5 . If at least one of the conditions

$$
\left|I\left(\lambda^{(k+1)}(\cdot), v^{(k+1)}\right)-I\left(\lambda^{(k)}(\cdot), v^{(k)}\right)\right| \leq \varepsilon_{1},
$$

or

$$
\left\|\lambda^{(k+1)}(\cdot)-\lambda^{(k)}(\cdot)\right\| \leq \varepsilon_{2},
$$

is fulfilled, then go to step 6 , otherwise, go to the $(k+2)$ th step.

6. Put $\quad \lambda_{i}^{*}(x)=\lambda_{i}^{(l)}(x), \quad i=\overline{1, N}, \quad v_{i j}^{*}=v_{i j}^{(l)}$, $i=\overline{1, N}, j=\overline{1, M}$, where $l-$ is the number of iteration at 
which the pair $\left(\lambda^{(l)}(\cdot), v^{(l)}\right)$ satisfies condition (16) or (17) of the completion of the iterative process.

7. Compute the optimal value of the objective functional by formula (15) under $\lambda_{i}(x)=\lambda_{i}^{*}(x), i=\overline{1, N}$, $x \in \Omega ; \quad v_{i j}=v_{i j}^{*}, \quad i=\overline{1, N}, j=\overline{1, M}$, and, to check the calculations correctness, - the value of the dual functional by the formula

$$
\begin{aligned}
& G_{1}(\psi, \eta)=\int_{\Omega} \min _{k}\left(c_{k}^{I}\left(x, \tau_{k}^{I}\right)+\psi_{k}\right) \rho(x) d x+ \\
& +\sum_{i=1}^{N} \sum_{j=1}^{M}\left(c_{i j}^{I I}\left(\tau_{i}^{I}, \tau_{j}^{I I}\right)+a_{i}-\eta_{j}-\psi_{i}\right) v_{i j}+\sum_{j=1}^{M} \eta_{j} b_{j}^{I I} .
\end{aligned}
$$

under $\psi_{i}=\psi_{i}^{*}, i=\overline{1, N}$ and $\eta_{j}=\eta_{j}^{*}, j=\overline{1, M}$.

The description of the algorithm 1 is completed.

To develop an algorithm for solving the continuous problem of OPSAC based on the necessary and sufficient optimality conditions given above, we rewrite problem (8) in the following form:

$$
\begin{aligned}
& \max _{\psi \in R^{N}, \eta \in R^{M}} G(\psi, \eta)= \\
& =\min _{\left\{\tau^{I}, v\right\} \in \Omega^{N} \times R_{N M}^{+}} G_{1}\left(\left\{\tau^{I}, v\right\}, \psi, \eta\right)= \\
& \left\{\tau^{I}, v\right\} \in \Omega^{N} \times R_{N M}^{+} \\
& =\min _{\psi \in R^{N}, \eta \in R^{M}} G_{1}\left(\left\{\tau^{I}, v\right\}, \psi, \eta\right)= \\
& =\min _{\tau^{I} \in \Omega^{N}} \max _{v \in R_{N M}^{+}} \max _{\psi \in R^{N}, \eta \in R^{M}} G_{1}\left(\left\{\tau^{I}, v\right\}, \psi, \eta\right)= \\
& =\min _{\tau^{I} \in \Omega^{N}} Q\left(\tau^{I}\right),
\end{aligned}
$$

where

$$
Q\left(\tau^{I}\right)=\min _{v \in R_{N M}^{+}} \max _{\psi \in R^{N}, \eta \in R^{M}} G_{1}\left(\left\{\tau^{I}, v\right\}, \psi, \eta\right) .
$$

Given arbitrary fixed values $\tau^{I} \in \Omega^{N}$ the value $Q\left(\tau^{I}\right)$ is an optimum value of the dual functional, which constructed for the continuous problem of OPSAC with fixed centers. Therefore, algorithm 1 is an integral part of the algorithm for solving problem B below. The key role is assigned to the method of generalized gradient ascent with space dilatation in the direction of the difference of two sequential gradients, i.e., the $r$-algorithm of N. Z. Shor [29], which is successfully used to find the local unconditional minimum of nonsmooth functions of several variables.

\section{Algorithm 2.}

Initialization. Choose $\tau^{I(0)} \in \Omega^{N}$ - initial approximation of set of $N$ points.
Using algorithm 1, compute values of characteristic functions of subsets $\lambda^{(0)}(x)$ at each point $x \in \Omega$, and initial approximation of parameters $v_{i j}^{(0)}, \quad i=\overline{1, N}$, $j=\overline{1, M}$.

Compute components $g_{Q}\left(\tau^{I(0)}\right)$ of the generalized gradient of the function $Q\left(\tau^{I}\right)$ at the point $\tau^{I(0)}$ by formulas:

$$
g_{Q}^{\tau_{i}^{I}}=\int_{\Omega} \rho(x) g_{c_{i}^{I}}^{\tau_{i}^{I}} \lambda_{i}(x) d x+\sum_{i=1}^{N} \sum_{j=1}^{M} g_{c_{i j}^{I I}}^{\tau_{I}^{I}} v_{i j}, i=\overline{1, N},
$$

with $\lambda=\lambda^{(0)}, v=v^{(0)}$. Here $g_{c_{i}^{I}}^{\tau_{i}^{I}}, g_{c_{i j}^{I I}}^{\tau_{i}^{I}}-i$-th components of the $N$-dimensional vectors $g_{c_{i}^{I}}(x, \tau)$ and $g_{c_{i j}^{I I}}\left(\tau, \tau^{I I}\right)$ of generalized gradients of the function $c_{i}^{I}\left(x, \tau_{i}^{I}\right)$ and $c^{I I}\left(\tau_{i}^{I}, \tau_{j}^{I I}\right), i=1, \ldots, N, \quad i=1, \ldots, M$, respectively at the point $\tau^{I}=\left(\tau_{1}^{I}, \ldots, \tau_{i}^{I}, \ldots, \tau_{N}^{I}\right), \tau_{i}=\left(\tau_{i}^{(1)}, \tau_{i}^{(2)}\right)$.

Define $H_{0}=I_{2 N}$ (identity matrix) and choose parameters $\alpha>1, \beta=\frac{1}{\alpha}<1$.

$$
k=0 \text {. }
$$

1. Let, as a result of performing $k, k=1,2 \ldots$ steps of the algorithm, definite values of $\tau^{I(k)} \in \Omega^{N}$; $\alpha_{k}=\alpha, \beta_{k}=\beta$.

2. Using algorithm 1 , compute values of characteristic functions of subsets $\lambda^{(k)}(x)$ at each point $x \in \Omega$, and current approximation of parameters $v_{i j}^{(k)}, i=\overline{1, N}$, $j=\overline{1, M}$.

3. Compute components of the generalized gradient vector $g_{Q}\left(\tau^{I(k)}\right)$ of function $Q\left(\tau^{I}\right)$ at point $\tau^{I(k)}$ by formulas (18) with $\lambda=\lambda^{(k)}, v=v^{(k)}$.

4. Compute next approximation $\tau^{I(k+1)}$ by formula

$$
\tau^{I(k+1)}=\mathrm{P}_{\Omega^{N}}\left(\tau^{I(k)}-h_{k} \frac{\mathrm{H}_{k} g_{Q}\left(\tau^{I(k)}\right)}{\sqrt{\left(\mathrm{H}_{k} g_{Q}\left(\tau^{I(k)}\right), g_{Q}\left(\tau^{I(k)}\right)\right)}}\right),
$$

where $\mathrm{P}_{\Omega^{N}}$ - is the operator of projection onto the set $\Omega^{N} ; h_{k} \geq 0-$ is a step multiplier chosen under the condition of the optimum of the function along the direction $p_{k}=-H_{k} g_{Q}\left(x^{k}\right)$.

5. Compute components of the generalized gradient vector $g_{Q}\left(\tau^{I(k+1)}\right)$ of function $Q\left(\tau^{I}\right)$ at the point $\tau^{I(k+1)}$ by formulas (18).

6. Let $r_{k}=g_{Q}\left(\tau^{I(k+1)}\right)-g_{Q}\left(\tau^{I(k)}\right)$. 
7. Compute matrix

$$
\begin{aligned}
H_{k+1} & =H_{k}+\left(\beta^{2}-1\right) \frac{H_{k} r_{k} r_{k}^{\mathrm{T}} H_{k}}{\left(H_{k} r_{k}, r_{k}\right)}= \\
& =H_{k}+\left(\beta^{2}-1\right) \frac{H_{k} r_{k} r_{k}^{\mathrm{T}} H_{k}}{r_{k}^{T} H_{k} r_{k}} .
\end{aligned}
$$

If at least one of the conditions

$$
\left|Q^{(k+1)}-Q^{(k)}\right|<\varepsilon \text { or }\left\|\tau^{I(k+1)}-\tau^{I(k)}\right\|<\varepsilon, \varepsilon>0,
$$

is fulfilled, then the end of algorithm, otherwise, $k:=k+1$ and go to the step 2 .

The description of the algorithm 2 is completed.

Note. In algorithm 2 conditions $\tau^{I} \in \Omega^{N}$ are accounted by the operator of projection $\mathrm{P}_{\Omega^{N}}$. Therefore, algorithm 2 can be applied to solve the continuous problem of OPSAC only if the set $\Omega$ is convex, closed, and has a rather simple structure that does not call solving the auxiliary problem of conditional optimization for finding the projection of a point on the set. If structure of $\Omega$ is rather complicated, then its form should be described by inequality constraints. For taking into account of such constraints, in turn, non-smooth penalty functions can be used.

\section{EXPERIMENTS}

Algorithms 1 and 2 are implemented in a software environment Delphi 7.0 when the set $\Omega$ is a square $\Omega=\{(x, y): 0 \leq x \leq 1,0 \leq y \leq 1\}$.

The numerical realization of algorithms presupposes the discretization of the given domain. To calculate multiple integrals, the cubature formula of the trapezium is used in the developed program. Problem (11)-(14) is solved using the method of potentials.

A number of computational experiments were carried out, while the studies were aimed at:

- checking the correctness of the algorithms;
- revealing the dependence of the functional value and the computing time on the size of the region discretization grid;

- clarifying the parameters that determine the shape of the boundaries between subsets in problems with fixed centers of the first stage;

- substantiation of the expediency of formulating and solving continuous problems of OPSAC in the organization of systems of two-stage transportation of material (raw) resources, entirely occupied by a certain territory.

In all the experiments, the results of which are given below: $\varepsilon_{1}=0.0001, \varepsilon_{2}=0.001$; parameters of $r$ algorithm: $\quad \alpha=3, \beta=0.9, \quad \varepsilon=10^{-4} ; \quad \rho(x)=1 \forall x \in \Omega$; $a_{i}=0 \forall i=\overline{1, N}$; for all $i=\overline{1, N}, j=\overline{1, M}$

$$
\begin{gathered}
c_{i}^{I}\left(x, \tau_{i}^{I}\right)=\sqrt{\left(x_{1}-\tau_{1 i}^{I}\right)^{2}+\left(x_{2}-\tau_{2 i}^{I}\right)^{2}}, \\
c_{i j}^{I I}\left(\tau_{i}^{I}, \tau_{j}^{I I}\right)=\sqrt{\left(\tau_{1 i}^{I}-\tau_{1 j}^{I I}\right)^{2}+\left(\tau_{2 i}^{I}-\tau_{2 j}^{I I}\right)^{2}} .
\end{gathered}
$$

\section{RESULTS}

To assess the effect of the discretization grid size on the running time of algorithm 1 , as well as on the value of the problem functional and the optimal partitioning of set, the same problem of OPSAC with different grid density was solved. In Fig. 2 it is represented a graph of the dependence of the running time of algorithm 1 on the grid size when solving model problem 1 with the following initial data: $\quad N=4, \quad M=2, \quad \tau_{1}^{I}=(0.97 ; 0.1)$, $\tau_{2}^{I}=(0.86 ; 0.03), \quad \tau_{3}^{I}=(0.87 ; 0.84), \quad \tau_{4}^{I}=(0.47 ; 0.7)$; $\tau_{1}^{I I}=(0.33 ; 0.26), \tau_{2}^{I I}=(0.73 ; 0.31) ; b^{I I}=(0.45 ; 0.55)$. The constructed trend line shows that the algorithm works in time $T(n)=O\left(n^{4}\right)$, where $n$ - grid size.

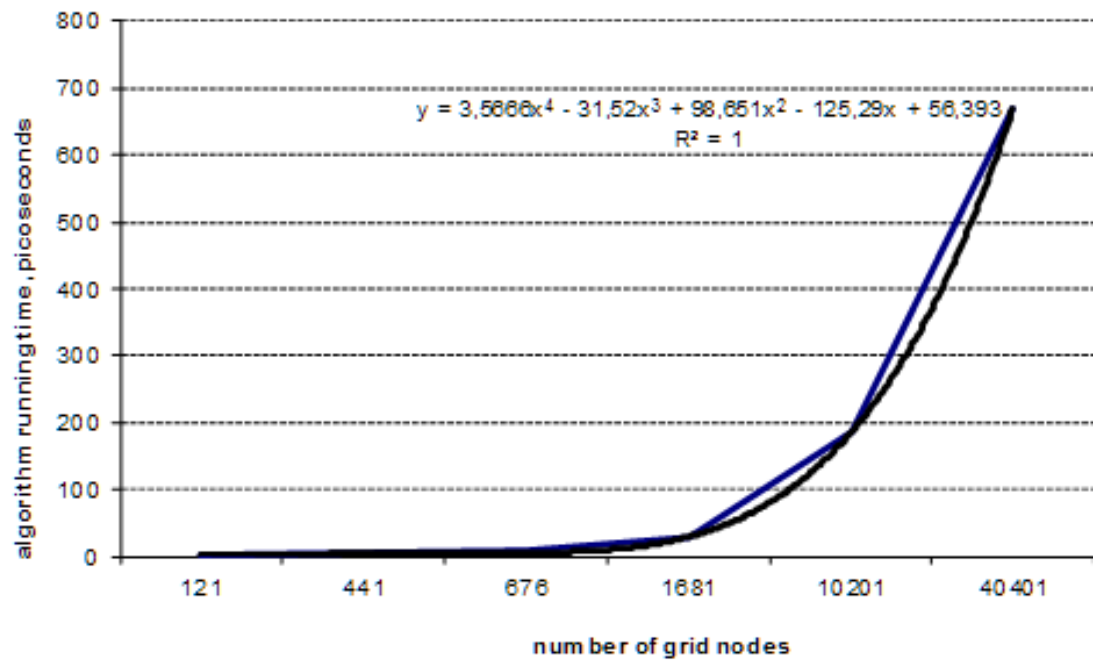

Figure 2 - The graph of the dependence of the running time of algorithm 1 on the size of the discretization grid 
Fig. 3 shows the optimal partitioning of the set and the scheme of couplings obtained in solving the problem of OPSAC for different region discretization grids. Of course, there was a slight difference in the values of the objective functional, which is explained, firstly, by the approximate computing of subsets cardinalities, and, consequently, in the sizes of supplies between the points of the first and second stages (see table 1 and 2). Secondly, as is known, the discretization grid fragmentation does not always improve the result of calculating multiple integrals.

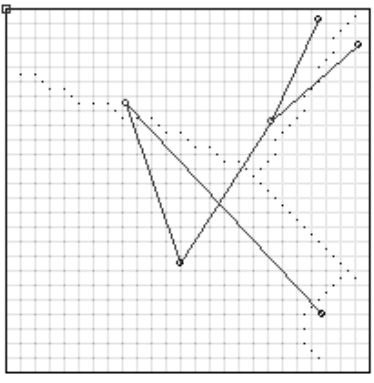

a

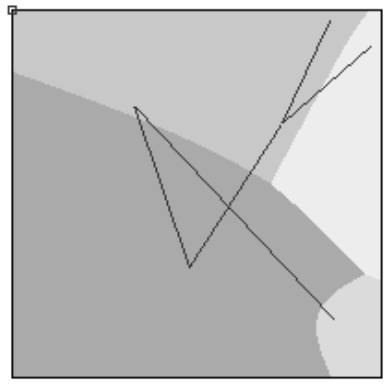

b
Figure 3 - Optimal partitioning of set and a communication scheme for different grid densities: $a-0.04 \times 0.04 ; b-0.005 \times 0.005$

Table 1 - Areas of subsets that constitute the optimal partition of set $\Omega$ in the modal problem 1

\begin{tabular}{|c|c|c|}
\hline \multirow{2}{*}{ Subset } & \multicolumn{2}{|c|}{ Value $b_{i}^{I}$, computed with grid step } \\
\cline { 2 - 3 } & $h_{1}=h_{2}=0.04$ & $h_{1}=h_{2}=0.005$ \\
\hline$\Omega_{1}$ & 0.1136 & 0.1218 \\
\hline$\Omega_{2}$ & 0.2495 & 0.2708 \\
\hline$\Omega_{3}$ & 0.032 & 0.0403 \\
\hline$\Omega_{4}$ & 0.5263 & 0.5568 \\
\hline
\end{tabular}

Table 2-Optimal supply volumes between the centers of the first and second stages in the model problem 1

\begin{tabular}{|c|c|c|}
\hline \multirow{2}{*}{} & \multicolumn{2}{|c|}{$\begin{array}{c}\text { Supply volumes calculated at such } \\
\text { discretization grid }\end{array}$} \\
\cline { 2 - 3 } & $h_{1}=h_{2}=0.04$ & $h_{1}=h_{2}=0.005$ \\
\hline$v_{11}$ & 0.1136 & 0.1218 \\
\hline$v_{12}$ & 0 & 0 \\
\hline$v_{21}$ & 0.2496 & 0.2709 \\
\hline$v_{22}$ & 0 & 0 \\
\hline$v_{31}$ & 0 & 0 \\
\hline$v_{32}$ & 0.032 & 0.0404 \\
\hline$v_{41}$ & 0.0913 & 0.0618 \\
\hline$v_{42}$ & 0.435 & 0.4951 \\
\hline
\end{tabular}

Observations of the objective functional value at each iteration of algorithm 1 in solving a number of continuous problems of OPSAC with fixed centers show that (C) Us S. A., Koriashkina L. S., Stanina O. D., 2019 DOI 10.15588/1607-3274-2019-1-24 algorithm 1 allows to construct a solutions approximations sequence on which the functional gradually decreases. In addition, the balance condition (6), and, consequently, the conditions (2), (3) is satisfied (with an accuracy of calculating the double integrals by the cubature formula of trapezoids). All this testifies to the correctness of the Algorithm 1 operation.

The correctness of the Algorithm 1 operation is also confirmed by the hyperbolic form of the boundaries between the subsets that constitute the optimal set partitioning. Here we give a solution of model problem 2 with such data:

- region discretization grid $-101 \times 101=10201$;

- $N=2 ; M=12 ; b_{j}^{I I}=0.076, j=\overline{1,11}, b_{12}^{I I}=0.166$;

- centers $\tau_{j}^{I I}, j=\overline{1,12}$, are marked in Fig. 4a, 4b;

- first stage centers: a) $\tau_{1}^{I}=(0.89 ; 0.12)$, $\tau_{2}^{I}=(0.43 ; 0.23) ;$ б) $\tau_{1}^{I}=(0.36 ; 0.59), \tau_{2}^{I}=(0.7 ; 0.57)$.

The optimal partitions and couplings are shown in Fig. $4 \mathrm{a}$ and $4 \mathrm{~b}$ respectively. The corresponding optimal values of the target functional and dual variables $\psi_{1}, \psi_{2}$ are presented there.

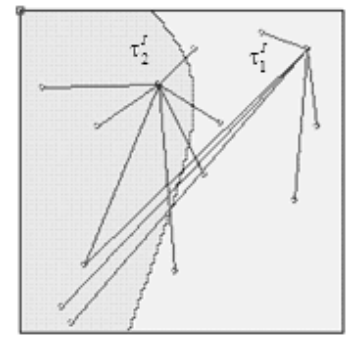

a

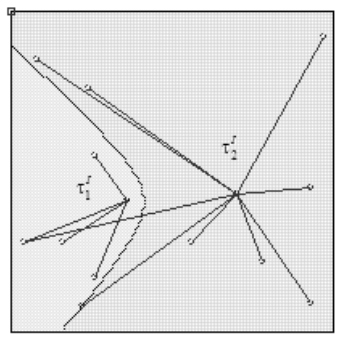

b
Figure 4-Optimal partition of set $\Omega$ and communication scheme in the modal problem 2:

$$
\begin{aligned}
& \mathrm{a}-\mathrm{I}=1.285 ; \psi_{1}=-0.265 ; \psi_{2}=0.0 ; \\
& \mathrm{b}-\mathrm{I}=1.246 ; \psi_{1}=0.236 ; \psi_{2}=0.0
\end{aligned}
$$

Let us examine the effect of the dual variables to form the boundaries between the subsets. In Fig. 4a boundary between subsets $\Omega_{1}$ and $\Omega_{2}$ curved in the direction from $\tau_{1}^{I}$ to $\tau_{2}^{I}$, while in Fig. $4 \mathrm{~b}-$ in the opposite direction. This is explained by the analytical form of the boundaries between the subsets, which is determined by formula (7), and the negative and positive value of the variable $\psi_{1}$ in the optimal solution of the problem. The supplies volumes and capacity of the centers of the first stage are given in Tables 3 and 4 respectively.

The results of other computational experiments for the solving of the OPSAC problem with fixed centers are presented without a detailed description in Fig. 5-7.

It should be noted that an increase in the number of centers of the first stage with unchanged other initial data 
does not significantly affect the running time of algorithm 1. The changes are appeared only in set partitioning shredding (in accordance with a given number of first stage centers), and in the sizes of supplies between the centers of both stages.

It was noticed that at the beginning with the appearance of each additional first stage center the functional value gradually decreases. This obviously takes place due to a reduction in the cost of delivery of the resource collected from the relevant areas to first stage centers. Although the cost of transporting the resource from the first stage centers to the second stage centers can increase. Subsequently, such an increase in the resource transportation cost is compensated by a reduction in transport costs for smaller quantity of the product transported from the centers of the first stage to consumers.

Table 3 - Supply volumes between the centers of the first and second stages in the model problem $2 \mathrm{a}$

\begin{tabular}{|l|c|c|c|c|c|c|c|c|c|c|c|c|c|}
\hline & $\tau_{1}^{I I}$ & $\tau_{2}^{I I}$ & $\tau_{3}^{I I}$ & $\tau_{4}^{I I}$ & $\tau_{5}^{I I}$ & $\tau_{6}^{I I}$ & $\tau_{7}^{I I}$ & $\tau_{8}^{I I}$ & $\tau_{9}^{I I}$ & $\tau_{10}^{I I}$ & $\tau_{11}^{I I}$ & $\tau_{12}^{I I}$ & $b_{i}^{I}$ \\
\hline$\tau_{1}^{I}$ & 0.076 & 0 & 0 & 0.076 & 0 & 0 & 0 & 0.076 & 0 & 0.076 & 0.075 & 0.167 & 0.544 \\
\hline$\tau_{2}^{I}$ & 0 & 0.076 & 0.076 & 0 & 0.076 & 0.076 & 0.076 & 0 & 0.076 & 0 & 0.001 & 0 & 0.455 \\
\hline
\end{tabular}

Table 4 - Supply volumes between the centers of the first and second stages in the model problem $2 \mathrm{~b}$

\begin{tabular}{|c|c|c|c|c|c|c|c|c|c|c|c|c|c|}
\hline & $\tau_{1}^{I I}$ & $\tau_{2}^{I I}$ & $\tau_{3}^{I I}$ & $\tau_{4}^{I I}$ & $\tau_{5}^{I I}$ & $\tau_{6}^{I I}$ & $\tau_{7}^{I I}$ & $\tau_{8}^{I I}$ & $\tau_{9}^{I I}$ & $\tau_{10}^{I I}$ & $\tau_{11}^{I I}$ & $\tau_{12}^{I I}$ & $b_{i}^{I}$ \\
\hline$\tau_{1}^{I}$ & 0 & 0.076 & 0.076 & 0 & 0 & 0 & 0 & 0 & 0.076 & 0.028 & 0 & 0 & 0.235 \\
\hline$\tau_{2}^{I}$ & 0.076 & 0 & 0 & 0.076 & 0.076 & 0.076 & 0.076 & 0.012 & 0 & 0.047 & 0.076 & 0.167 & 0.745 \\
\hline
\end{tabular}

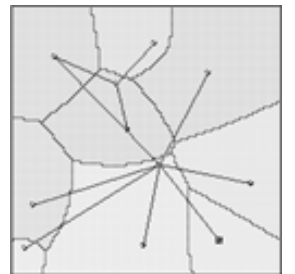

a

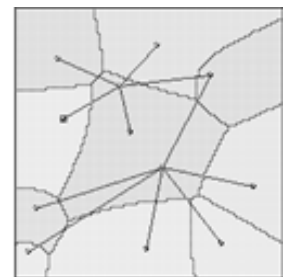

$\mathrm{b}$

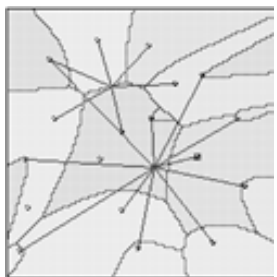

c

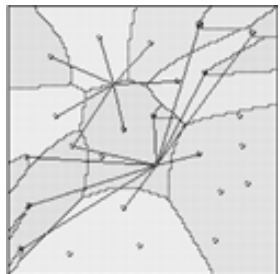

d

Figure 5 - Optimal partition of set $\Omega$ and communication scheme in the SSPAC at $M=2$ :

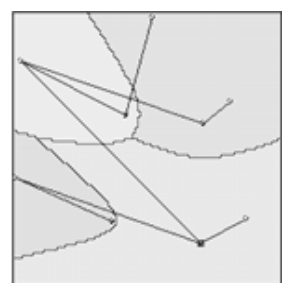

a

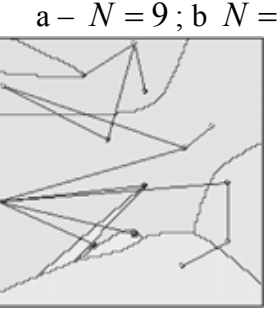

b

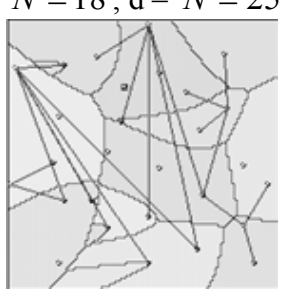

c

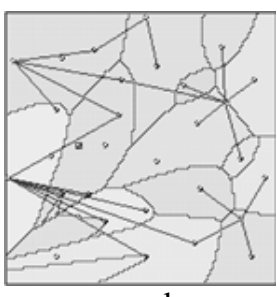

d

Figure 6-Optimal partition of set $\Omega$ and communication scheme in the SSPAC at $M=5$ :

$$
\mathrm{a}-N=4 ; \mathrm{b}-N=9 ; \mathrm{c}-N=23 ; \mathrm{d}-N=25
$$

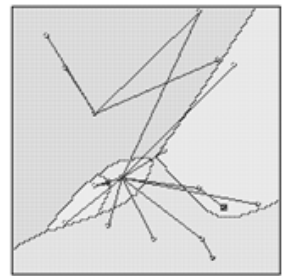

a

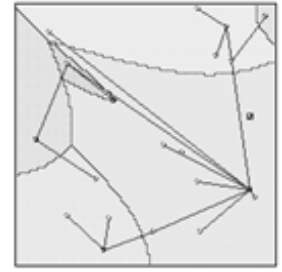

$\mathrm{b}$

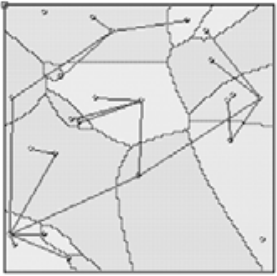

$\mathrm{c}$

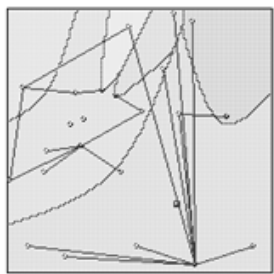

d

Figure 7 - Optimal partition of set $\Omega$ and connection scheme in the SSPAC with such data:

$$
\begin{gathered}
\mathrm{a}-N=5, M=13 ; b_{j}^{I I}=0.07, j=\overline{1,12}, b_{13}^{I I}=0.06 ; \mathrm{b}-N=8, M=13 ; b_{j}^{I I}=0.07, j=\overline{1,12}, b_{13}^{I I}=0.06 ; \\
\mathrm{c}-N=18, M=6 ; b_{j}^{I I}=0.15, j=\overline{1,5}, b_{10}^{I I}=0.25 ; \mathrm{d}-N=9, M=15 ; b_{j}^{I I}=0.06, j=\overline{1,14}, b_{10}^{I I}=0.16
\end{gathered}
$$


The ambiguous nature of the functional value change is due to the choice of the location of the each next center. But, since the total amount of the resource distributed on a given set does not change, the quantity of the product delivered by each center of the first stage to the centers of the second stage is less and less. Therefore, it makes no sense to formulate the task of OPSAC with the location a large number of the first stage centers.

In addition, when solving the tasks of an OPSAC with a sufficiently large value of $\mathrm{N}$, it may turn out that some of the centers will acquire the status of fictitious ones, that is, these centers will not be assigned any zone that they can serve. This is exactly what happens in Fig. 5c,d, 7c,d.

Detailed description and analysis of the results of solving many continuous problems of OPSAC with the location of the first stage centers is not possible within the framework of this article. Here we give only those that indicate the correctness of the algorithm 2 operation and the desirability of describing two-stage logistics processes with a resource entirely occupied by some territory in the form of continuous problems of OPSAC.

Modal problem 3 (with centers locating).

Initial data: $\quad N=M=2 ; \quad b^{I I}=(0.5 ; 0.5)$; $\tau_{1}^{I I}=(0.25 ; 0.5), \quad \tau_{2}^{I I}=(0.75 ; 0.5) ; \quad \tau_{1}^{(0)}=(0.1 ; 0.3)$, $\tau_{2}^{(0)}=(0.8 ; 0.6)$.

The following values are obtained at the 58th iteration of $\quad$ r-algorithm: $\quad I=0.3039 ; \quad \tau_{1}^{I^{*}}=(0.263 ; 0.498)$, $\tau_{2}^{I^{*}}=(0.752 ; 0.5) ; v_{11}^{*}=0.5, v_{12}^{*}=0.017, v_{22}^{*}=0.483$. Optimal partitioning and location of centers are presented in Fig. 8.

Thus, in solving problem 3 , in which the centers of the second stage coincide with the points $(0.25,0.5)$ and $(0.75,0.5)$, the centers of the first stage were located almost at the same points. The optimal partitioning of square is the classical Dirichlet-Voronoi diagram for these points. In this case, the second term of the objective functional is almost zero, and the first equals with the minimum value of the quality criterion in the problem of optimal partitioning of the unit square into two subsets with the placement of centers.

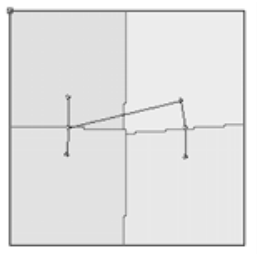

a

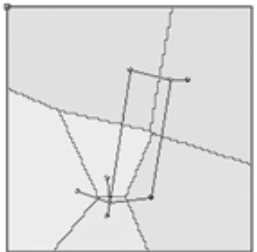

b

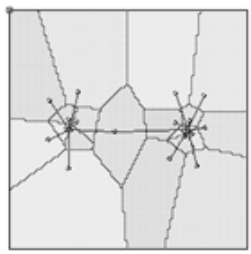

c

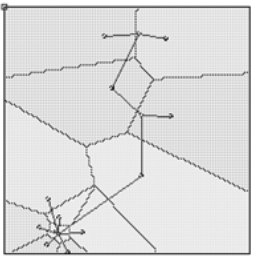

d

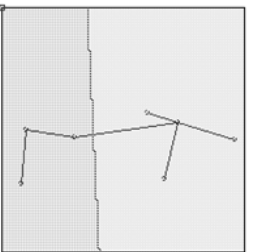

e

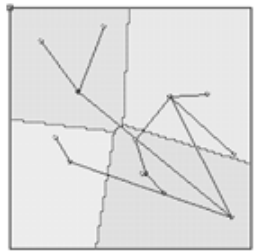

f

Figure 9 - Optimal partition of set $\Omega$ and communication scheme in the SSPAC with locating of first-stage centers at such data:

$$
\begin{gathered}
\mathrm{a}-N=4, M=2 ; b_{j}^{I I}=0.5, j=1,2 ; \mathrm{b}-N=6, M=2 ; b_{j}^{I I}=0.5, j=1,2 ; \\
\mathrm{c}-N=20, M, b_{j}^{I I}, j=1,2-\text { the same; } \mathrm{d}-N=12, M=3, b^{I I}=(0,31 ; 0.32 ; 0.37) ; \mathrm{e}-N=2, M=5 ; \\
b^{I I}=(0.18 ; 0.17 ; 0.19 .0 .18 ; 0.19) ; \mathrm{f}-N=4, M=9 ; b^{I I}=(0.1 ; 0.12 ; 0.1 ; 0.12 ; 0.09 ; 0.1 ; 0.1 .0 .1 ; 0.16)
\end{gathered}
$$


be the "centers of gravity" of polygons, which are convex hulls of points corresponding to the nearest first stage centers. The optimal partition is the Dirichlet-Voronoi diagram. The boundaries between subsets are straight lines, in contrast to the hyperbolic form of the boundaries between the subsets that constitute the optimal region partitioning in problems of OPSAC with fixed first stage centers.

In conclusion, we give an example that shows how important to formulate optimization problems for twostage logistical processes with a continuously distributed resource in the form of problems (1)-(5) to obtain a synergistic effect. Imagine a situation where the resource is uniformly distributed on the same unit square. It is necessary to find partitioning of the square into 10 zones, place the corresponding centers and determine their possible couplings with the two centers of the second stage (with demands $b_{1}^{I I}=b_{2}^{I I}=0.5$ ) to minimize the total costs for the resource transportation to the centers of the first stage and the costs of further transportation of the resource to the centers of the first stage. The location of the second stage centers is shown in Fig. 10a. This figure also shows the optimal location of the first-stage centers, their corresponding service areas, and also indicates the additional couplings between the centers of the first and second stages. The value of the objective functional with such a location-allocation is $I=0.33069$.

If, on the other hand, first the OPS problem with the location of the centers and the criterion of the quality of the partition, equal to the first term of the functional (1), and then, with the obtained coordinates of the centers of the first stage, the transport type problem with the criterion equal to the second term in (1) to obtain the optimal location of the centers of the first stage and the corresponding zones shown in Fig. 10b.

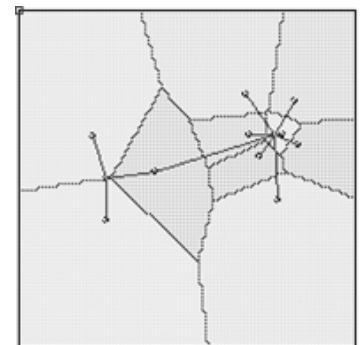

a

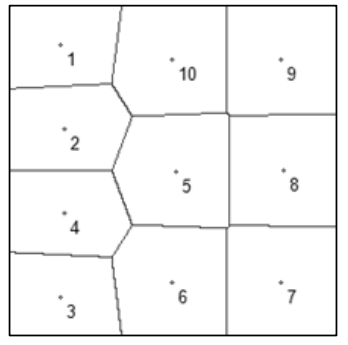

$\mathrm{b}$
Figure 10 - Optimal partition of set $\Omega$ and optimal location of centers in the problem: a - SPP with additional constraints; $\mathrm{b}$ - SPP with locating of subsets centers

The values of the objective functionals of the two problems are: $I_{1}=0,1222$ and $I_{2}=0.300964$ respectively, which in total is $I_{1}+I_{2}=0.423164$. And thus, the gain in the value of the objective functional in the modeling of a two-stage logistical process in the form of a continuous problem of OPSAC is obvious.

\section{DISCUSSION}

The results of computational experiments allow to make the following conclusions about optimal solutions of continuous multi-stage location-allocation problems.

1. If the first stage centers are fixed in the OPSAC problem, then the boundaries between the subsets, making up the optimal partition of the given region, are hyperbolas. This fact is completely consistent with analytic results (a corollary 1) and agree with the theoretical justification of the form of the boundary between the subsets making up optimal partitions in problems of OPS under constraints in the form of equalities and inequalities [27, 29].

2. In the optimal solutions to the OPSAC problems the first stage centers are usually located in groups near the centers of the second stage. In this case the components of the vector $\psi$ of dual variables often turn out to be close to zero, as a result of which the optimal partitions of sets are the classical Dirichlet-Voronoi diagrams constructed for the placed points.

3. If the number of centers of the second stage is much less than the number of the centers of the first stage in OPSAC problems with fixed centers, then some of the corresponding ones' areas can be empty. Therefore, when solving continuous OPSAC problems, one can get an answer to the question of the rational number of first stage centers, which will be enough to collect the entire continuously distributed resource at the relevant areas and with minimum costs to transport the processed product to the second stage centers.

The results of the computational experiments testify to the correctness of the algorithms operation. Both algorithms search for a local (sometimes global) minimum of the objective functional. The reliability of the obtained results is confirmed by their consistency with theoretical research and logically reasoned expected outcomes.

\section{CONCLUSIONS}

It is solved the actual problem related to the optimal organization of two-stage material flows distribution processes in the transport-logistical system, the structural elements of which are enterprises that collect a certain resource continuously distributed on a certain territory, and enterprises that consume or process this resource.

The scientific novelty of obtained results is to construct mathematical models of problems that allow to quantitatively justify the decision to locate a two-stage production, the raw material resource of which is continuously distributed in some territory. Methods and algorithms for solving problems of optimal partitioning of a continual set with placement of centers of subsets and additional connections due to the presence of the second stage are presented. It is shown that a system approach to solving the issues of placement of two-stage production 
makes it possible to obtain a synergistic effect that affects the overall goal of the logistics system.

The practical significance of the obtained results is the developed software that implements the proposed algorithms for solving continuous OPSAC problems and can be used in practice when creating territorially distributed multilevel companies that perform a full cycle of production from raw material harvesting with its integrated use, transportation to end customers. The introduction of the proposed approach to the accounting of two-stage transportation of a continuously distributed resource on a given territory to the end user will ensure a reduction in costs for the advancement of material flows, as well as an increase in the efficiency of the use of natural resources.

Prospects for further research are theoretical justification of the convergence of the iterative process realized in the proposed algorithm for solving continuous problems of ORM with additional constraints, as well as the development of software for solving such problems with the use of GIS technologies.

\section{REFERENCES}

1. Esin K. S., Sevost'janov A. L. Matematicheskaja model' raspredelenija perevozimyh ob'emov zerna s vremennyh punktov hranenija potrebitelju, Vestnik TOGU, 2015, No. 4(39), pp. 145-152.

2. Mironjuk V. P., Cyplakov V. Ju. Model' formirovanija sistemy dvuhjetapnogo transportirovanija tverdyh municipal'nyh othodov, Upravlenie bol'shimi sistemami, 2011, Vyp. 37, pp. 208-231.

3. Voronin A. V. Mnogojetapnye zadachi planirova-nija i upravlenija material'nymi potokami v verti-kal'nointegrirovannyh strukturah lesopromysh-lennogo kompleksa, Lesnoj zhurnal, 2003, No. 2-3, pp. 123-133.

4. Gimadi Je. H., Kurochkin A. A. Jeffektivnyj algoritm reshenija dvuhjetapnoj zadachi razmeshhenija na drevovidnoj seti, Diskretnyj analiz i issledovanie operacij, Nojabr', dekabr', 2012, Vol. 19, No. 6, pp. 9-22.

5. Montlevich V. M. Zadacha razmeshhenija predprijatij $s$ tipovymi moshhnostjami i nedelimymi potrebitelja-mi, $Z$ h. vychisl. matem. i matem. fiz, 40:10, 2000, pp. 1491-1507.

6. Trubin V. A., Sharifov F. A. Prostejshaja mnogojetapnaja zadacha razmeshhenija na drevovidnoj seti [Tekst], Kibernetika i sistemnyj analiz, 1992, No. 6, pp. 128-135.

7. Kolokolov A A., Levanova T.V., Fedorenko A. S. Issledovanie dekompozicionno-go podhoda dlja dvuhstadijnoj zadachi razmeshhenija, Vestnik Omskogo universiteta, 2010, No. 4, pp. 24-31.

8. Goncharov Y., Kochetov E. A behavior of a probabilistic tabu search algorithm for the multi stage uncapacitated facility location problem, Proceedings of the Operations Research, 2000, pp. 65-70.

9. Us S. A., Stanina O. D. Algoritm reshenija dvuhjetapnoj zadachi razmeshhenija proizvodstva s predpochtenijami, Sistemni tehnologii. Regional'nij mizhvuzivs'kij zbirnik naukovih prac', 2014, 2 (91), pp. 116-124.

10. Cheung Raymond K.-M., Powell Warren B. Models and Algorithms for Distribution Problems with Uncertain Demands, October, 1994, $36 \mathrm{p}$.

11. Erengüç S. S., Simpson N., Vakharia A. J. Integrated Production/Distribution Planning in Supply Chains - An
Invited Review, European Journal of Operational Research, 1999, Vol. 115, pp. 219-236.

12. Fisher M. L. What is the Right Supply Chain for Your Product?, Harvard Business Review, 1997, 75(2), MarchApril), pp. 105-116.

13. Hindi K. S., Basta T. Computationally efficient solution of a multiproduct, two stage distribution-location problem, The Journal of the Operational Research Society, 1994, 45 (11), pp. 1316-1323.

14. Tsiakis P., Shah N., Pantelides C. C. Design of Multiechelon Supply Chain Networks under Demand Uncertainty, Industrial \& Engineering Chemistry Research, 2001, 40 (16), pp. 3585-3604. DOI: 10.1021/ie0100030

15. Nozick L. K., Turnquist M. A. Inventory, transportation, service quality and the location of distribution centers, European Journal of Operational Research, 2001, 129, pp. 362-371.

16. Klose A., Drexl A. Facility location models for distribution system design, European Journal of Operational Research, 2005, 162, pp. 4-29.

17. Lai Kim-Teng. Luong Lee Hong Son, Marian Romeo Marin; Lee Moon-Kyu An Optimization Framework for Multistage Production-distribution Networks using Genetic Algorithms, 9th Global Congress on Manufacturing and Management, 2008, pp. 514-523.

18. Wollenweber J. A multi-stage facility location problem with staircase costs and splitting of commodities: model, heuristic approach and application, OR Spectrum, 2008, 30: 655. https://doi.org/10.1007/s00291-007-0114-3

19. Ming-Jong Yao Hsin-Wei Hsu. A new spanning tree-based genetic algorithm for the design of multi-stage supply chain networks with nonlinear transportation costs. Optim Eng, 2009, 10, pp. 219-237 DOI 10.1007/s11081-008-9059-x

20. Turan Paksoy, Ching-Ter Chang Revised multi-choice goal programming for multi-period, multi-stage inventory controlled supply chain model with popup stores in Guerrilla marketing, Applied Mathematical Modelling, 2010, Volume 34, Issue 11, November, pp. 3586-3598.

21. Mitsuo Gen, Admi Syarif. Multi-stage Supply Chain Network by Hybrid Genetic Algorithms. - Fuzzy Sets Based Heuristics for Optimization, Том 126, seriya Studies in Fuzziness and Soft Computing Springer, 2012, pp. 181-196.

22. Jesus Gonzalez-Feliu, Song H. Multi-stage LTL transport systems in supply chain management, Logistics: Perspectives, Approaches and Challenges, Nova Science Publishing, 2013, pp. 65-86.

23. Farahani R., Hekmatfar Masoud, Fahimnia Behnam, Kazemzadeh Narges Hierarchical facility location problem: Models, classifications, techniques, and applications, Computers \& Industrial Engineering 2014, 68, pp. 104-117.

24. Irawan C. A., Jones D. Formulation and solution of a twostage capacitated facility location problem with multilevel capacities Ann Oper Res, 2018. https://doi.org/10.1007/s10479-017-2741-7

25. Us S. A., Stanina O. D. O matematicheskih modeljah mnogo-jetapnyh zadach razmeshhenija predprijatij, Pitanija prikladnoï matematiki $i$ matematichnogo modeljuvannja: zb.nauk.pr, 2014, pp. 258-268.

26. Us S. A., Stanina O. D. Multi-stage problem of concentration plant location, 6th International Academic Conference of Young Scientists "Computer Science and Engineering 2013" (CSE-2013) / 4th International Youth Science Festival "Litteris et Artibus" November 21-23, 2013 Lviv Polytechnic National University, http://ena.lp.edu.ua:8080/handle/ntb/237 
27. Kiseleva E. M., Korjashkina L. S., Us S. A. Teorija optimal'nogo razbienija mnozhestv $\mathrm{V}$ zadachah raspoznovanija obrazov, analiza i identifi-kacii sistem: monografija. M-vo obrazovanija i nauki Ukrainy, GVNZ "Nac. gorn. un-t". Dnepropetrovsk, NGU, 2015, 270 p.

28. Zelentsov D. Us S., Koryashkina L., Stanina O. Solving Continual Two Problems of Optimal Partition of Sets Stage,
International Journal of Research Studies in Computer Science and Engineering (IJRSCSE), 2017, Volume 4, Issue 4, pp. 72-80.

29. Shor N. Z. Metody minimizacii nedifferenciruemyh funkcij i ih prilozhenie. Kiev, Nauk. dumka, 1979, 200 p.

Received 07.08.2018. Accepted 12.09.2018.

\section{УДК 519.8}

\section{ОПТИМІЗАЦІЯ ДВОЕТАПНОГО РОЗПОДІЛУ МАТЕРІАЛЬНИХ ПОТОКІВ У ТРАНСПОРТНО-ЛОГІСТИЧНІЙ СИСТЕМІ 3 РЕСУРСОМ, РОЗПОВСЮДЖЕНИМ НА ЗАДАНІЙ ТЕРИТОРІЇ}

Ус С. А. - канд. фіз.-мат. наук, професор кафедри системного аналізу і управління Національного ТУ «Дніпровська політехніка», Україна.

Коряшкіна Л. С. - канд. фіз.-мат. наук, доцент кафедри системного аналізу і управління Національного ТУ «Дніпровська політехніка», Україна.

Станіна О. Д. - асистент кафедри комп'ютерних інформаційних технологій ДВНЗ «Український державний хімікотехнологічний університет», Україна.

Актуальність. Об'єктом дослідження є двоетапний процес розподілу матеріальних потоків в транспортно-логістичній системі, структурними елементами якої є підприємства, які здійснюють збір деякого неперервно розповсюдженого на певній території ресурсу (центри першого етапу), і підприємства, що цей ресурс споживають або переробляють. Представлена математична модель такого процесу - задача оптимального розбиття континуальної множини 3 розміщенням центрів підмножин і додатковими зв'язками. Мета роботи - забезпечення зниження транспортних витрат при організації багатоетапного виробництва, сировинний ресурс якого розповсюджений на деякій території, за рахунок розробки відповідного математичного і програмного забезпечення. Актуальність роботи обумовлена однією 3 найбільш виражених тенденцій у видобувних і переробних галузях промисловості і сільського господарства, а саме - створенням територіальнорозподілених багаторівневих компаній, що включають в себе десятки великих підприємств і здійснюють повний цикл виробництва від заготівлі сировини з його комплексним використанням, випуском продукції до транспортування кінцевим споживачам.

Метод. Математичне забезпечення двоетапних задач розміщення-розподілу розроблено із використанням основних положень теорії неперервних лінійних задач оптимального розбиття множин з розміщенням центрів підмножин, теорії двоїстості, а також методів розв'язання задач лінійного програмування транспортного типу. Показано, що формулювання багатоетапної транспортно-логістичної задачі в неперервному варіанті (у вигляді задачі нескінченновимірної оптимізації) доцільно, коли кількість постачальників ресурсу дуже велика. Застосування розробленого математичного апарату дає можливість знайти оптимальний розв'язок двоетапної задачі розміщення-розподілу в аналітичному вигляді, хоча отриманий вираз містить параметри, які є оптимальним розв'язком допоміжної скінченновимірної оптимізаційної задачі 3 негладкою цільовою функцією. Запропоновано ітераційний алгоритм розв'язання сформульованої задачі, розроблений на основі $\mathrm{r}$ алгоритму Н.3. Шора і методу потенціалів, що застосовується для задач лінійного програмування транспортного типу.

Результати. Розроблено математичні моделі, методи та алгоритми розв'язання неперервних багатоетапних задач розміщення підприємств 3 неперервно-розподіленим ресурсом, на основі яких створено програмний продукт, що може бути використаний для розв'язання широкого класу неперервних лінійних задач розміщення - розподілу. Представлені методи, алгоритми та програмний продукт дозволяють вирішувати цілий ряд практичних проблем, пов'язаних, наприклад, iз задачами стратегічного планування, які виникають у виробничій, соціальній та економічній сферах діяльності. Отримані теоретичні результати доведені до рівня конкретних рекомендацій, які можуть бути використані державними і приватними підприємствами при вирішенні логістичних питань, пов'язаних 3 організацією збору певного ресурсу і його доставкою до пунктів переробки, а також подальшого перевезення отриманого продукту до місць призначення.

Висновки. Результати обчислювальних експериментів свідчать про коректність роботи запропонованого алгоритму розв'язання задачі оптимального розбиття множин (ОРM) 3 додатковими зв'язками, крім того, дають можливість стверджувати про доцільність формулювання таких задач, коли потрібно визначати на заданій території місця розташування нових об’єктів з урахуванням багатоетапного процесу розподілу деякого неперервно розповсюдженого ресурсу. Подальшому дослідженню підлягають питання теоретичного обгрунтування збіжності ітераційного процесу, реалізованого в запропонованому алгоритмі розв'язання неперервних задач ОРМ з додатковими зв'язками. У перспективі також розробка програмного забезпечення розв'язання таких задач із залученням ГІС-технологій.

КЛЮЧОВІ СЛОВА: багатоетапні транспортно-логістичні системи, неперервно розподілений ресурс, оптимальне розбиття множин, неперервні задачі розміщення-розподілу.

\section{УДК 519.8}

ОПТИМИЗАЦИЯ ДВУХЭТАПНОГО РАСПРЕДЕЛЕНИЯ МАТЕРИАЛЬНЫХ ПОТОКОВ В ТРАНСПОРТНОЛОГИСТИЧЕСКОЙ СИСТЕМЕ С РЕСУРСОМ, РАСПРОСТРАНЕННЫМ НА ЗАДАННОЙ ТЕРРИТОРИИ

Ус С. А. - канд. физ.-мат. наук, профессор кафедры системного анализа и управления Национального ТУ «Днепровская политехника», Украина. 
Коряшкина Л. С. - канд. физ.-мат. наук, доцент кафедры системного анализа и управления Национального ТУ «Днепровская политехника», Украина.

Станина О. Д. - ассистент кафедры компьютерных информационных технологий ДВНЗ «Украинский государственный химико-технологический университет», Украина.

\section{АННОТАЩИЯ}

Актуальность. Объектом исследования является двухэтапный процесс распределения материальных потоков в транспортно-логистической системе, структурными элементами которой являются предприятия, осуществляющие сбор некоторого непрерывно распространенного на определенной территории ресурса (центры первого этапа), и предприятия, которые этот ресурс потребляют или перерабатывают. Представлена математическая модель такого процесса - задача оптимального разбиения континуального множества с размещением центров подмножеств и дополнительными связями. Цель работы - обеспечение снижения транспортных затрат при организации многоэтапного производства, сырьевой ресурс которых распространен на некоторой территории, за счет разработки соответствующего математического и программного обеспечения. Актуальность работы обусловлена одной из наиболее выраженных тенденций в добывающих и перерабатывающих отраслях промышленности и сельского хозяйства, а именно - созданием территориальнораспределенных многоуровневых компаний, включающих в себя десятки крупных предприятий и осуществляющих полный цикл производства от заготовки сырья с его комплексным использованием, выпуском продукции до транспортировки конечным потребителям.

Метод. Математическое обеспечение двухэтапных задач размещения-распределения разработано с использованием основных положений теории непрерывных линейных задач оптимального разбиения множеств с размещением центров подмножеств, теории двойственности, а также методов решения задач линейного программирования транспортного типа. Показано, что формулирование многоэтапной транспортно-логистической задачи в непрерывном варианте (в виде задачи бесконечномерной оптимизации) целесообразно, когда количество поставщиков ресурса очень велико. Применение разработанного математического аппарата дает возможность найти оптимальное решение двухэтапной задачи размещенияраспределения в аналитическом виде, хотя аналитическое выражение содержит параметры, являющиеся оптимальным решением вспомогательной конечномерной оптимизационной задачи с негладкой целевой функцией. Предложен итерационный алгоритм решения сформулированной задачи, разработанный на основе r-алгоритма Н.3. Шора и метода потенциалов решения задач линейного программирования транспортного типа.

Результаты. Разработаны математические модели, методы и алгоритмы решения непрерывных многоэтапных задач размещения предприятий с непрерывно-распределенным ресурсом, на основе которых создан программный продукт, который может быть использован для решения широкого класса непрерывных линейных задач размещения распределения. Представленные методы, алгоритмы и программный продукт позволяют решать целый ряд практических проблем, связанных, например, с задачами стратегического планирования, которые возникают в производственной, социальной и экономической сферах деятельности. Полученные теоретические результаты доведены до уровня конкретных рекомендаций, которые могут быть использованы государственными и частными предприятиями при решении логистических задач, связанных с организацией сбора определенного ресурса и его доставкой до пунктов переработки, а также дальнейшей перевозки полученного продукта к местам назначения.

Выводы. Результаты вычислительных экспериментов свидетельствуют о корректности работы предложенного алгоритма решения непрерывной задачи оптимального разбиения множеств (ОРМ) с дополнительными связями, кроме того, дают возможность утверждать о целесообразности формулировки таких задач в случае, когда нужно определять на заданной территории места расположения новых объектов с учетом многоэтапного процесса распределения ресурса, непрерывно распространенного на заданной территории. Дальнейшему исследованию подлежат вопросы теоретического обоснования сходимости итерационного процесса, реализованного в предложенном алгоритме решения непрерывных задач ОРМ с дополнительными связями. В перспективе также - разработка программного обеспечения решения таких задач с привлечением ГИС-технологий.

КЛЮЧЕВЫЕ СЛОВА: многоэтапные транспортно-логистические системы, непрерывно распределенный ресурс, оптимальное разбиение множеств, непрерывные задачи размещения-распределения.

\section{ЛІТЕРАТУРА / ЛИТЕРАТУРА}

1. Есин К. С. Математическая модель распределения перевозимых объемов зерна с временных пунктов хранения потребителю / К. С. Есин, А. Л. Севостьянов // Вестник ТОГУ. - 2015. - № 4(39). - С. 145-152.

2. Миронюк В. П. Модель формирования системь двухэтапного транспортирования твердых муниципальных отходов / В. П. Миронюк, В. Ю. Цыплаков // Управление большими системами. 2011. - Вып. 37. - С. 208-231.

3. Воронин А. В. Многоэтапные задачи планирования и управления материальными потоками в вертикальноинтегрированных структурах лесопромышленного комплекса / А. В. Воронин // Лесной журнал. - 2003. № 2-3. - C. 123-133.

4. Гимади Э. Х. Эффективный алгоритм решения двухэтапной задачи размещения на древовидной сети /
Э. Х. Гимади, А. А. Курочкин // Дискретный анализ и оптимизация. - Ноябрь-декабрь, 2012. - Т. 19, № 6. C. $9-22$.

5. Монтлевич В.М. Задача размещения предприятий с типовыми мощностями и неделимыми потребителями // Ж. вычисл. матем. и матем. физ., 2000, 40:10. - С. 14911507.

6. Трубин В. А. Простейшая многоэтапная задача размещения на древовидной сети / В. А. Трубин, Ф. А. Шарифов // Кибернетика и системный анализ. 1992. - № 6. - C. 128-135.

7. Колоколов А. А. Исследование декомпозиционного подхода для двухстадийной задачи размещения / А. А. Колоколов, Т. В. Леванова, А. С. Федоренко // Вестник Омского университета. - 2010. - № 4. C. 24-31. 
8. Goncharov Y. A behavior of a probabilistic tabu search algorithm for the multi stage uncapacitated facility location problem / Y. Goncharov, E. Kochetov // Proceedings of the Operations Research. - 2000. - P. 65-70.

9. Ус С. А. Алгоритм решения двухэтапной задачи размещения производства с предпочтениями / С. А. Ус, О. Д. Станина // Системні технології. Регіональний міжвузівський збірник наукових праць. - 2014. 2 (91). - C. 116-124.

10. Cheung Raymond K.-M. Models and Algorithms for Distribution Problems with Uncertain Demands / Raymond K.-M. Cheung, Warren B. Powell. - October, 1994. - 36 p.

11. Erengüç S. S. Integrated Production/Distribution Planning in Supply Chains - An Invited Review / S. S. Erengüç, N. Simpson, A. J. Vakharia // European Journal of Operational Research. - 1999. - Vol. 115. - P. 219-236.

12. Fisher M. L. What is the Right Supply Chain for Your Product? / M. L. Fisher // Harvard Business Review. 1997. - 75 (2, March-April). - P. 105-116.

13. Hindi K. S. Computationally efficient solution of a multiproduct, two stage distribution-location problem / K. S. Hindi, T. Basta // The Journal of the Operational Research Society. - 1994. - 45 11. - P. 1316-1323.

14. Tsiakis P. Design of Multi-echelon Supply Chain Networks under Demand Uncertainty / P. Tsiakis, N. Shah, C. C. Pantelides // Industrial \& Engineering Chemistry Research. - 2001. - 40 (16). - P. 3585-3604. DOI: 10.1021/ie0100030

15. Nozick L. K. Inventory, transportation, service quality and the location of distribution centers / L. K. Nozick, M. A. Turnquist // European Journal of Operational Research. - 2001. - 129. - P. 362-371.

16. Klose A. Facility location models for distribution system design / A. Klose, A. Drexl // European Journal of Operational Research. - 2005. - 162. - P. 4-29.

17. An Optimization Framework for Multistage Productiondistribution Networks using Genetic Algorithms / [Lai Kim Teng, Luong Lee Hong Son, Marian Romeo Marin, Lee Moon-Kyu] // 9th Global Congress on Manufacturing and Management. - 2008. - P. 514-523.

18. Wollenweber J. A multi-stage facility location problem with staircase costs and splitting of commodities: model, heuristic approach and application / J. Wollenweber // OR Spectrum (2008) 30: 655. https://doi.org/10.1007/s00291-007-0114-3

19. Ming-Jong Yao Hsin-Wei Hsu. A new spanning tree-based genetic algorithm for the design of multi-stage supply chain networks with nonlinear transportation costs. Optim Eng (2009) 10: 219-237 DOI 10.1007/s11081-008-9059-x

20. Turan Paksoy. Revised multi-choice goal programming for multi-period, multi-stage inventory controlled supply chain model with popup stores in Guerrilla marketing / Turan Paksoy, Ching-Ter Chang // Applied Mathematical Modelling. - Volume 34, Issue 11, November 2010. P. 3586-3598.

21. Mitsuo Gen. Multi-stage Supply Chain Network by Hybrid Genetic Algorithms. - Fuzzy Sets Based Heuristics for Optimization / Mitsuo Gen, Admi Syarif, Verdegay J.-L. (ed.). - Part of the Studies in Fuzziness and Soft Computing book series (STUDFUZZ, volume 126) Springer, 2012. $\quad-\quad$ P. $181-196$. DOIhttps://doi.org/10.1007/978-3-540-36461-0

22. Jesus Gonzalez-Feliu. Multi-stage LTL transport systems in supply chain management. / J. Cheung, H. Song // Logistics: Perspectives, Approaches and Challenges, Nova Science Publishing, 2013. - P. 65-86.

23. Farahani R. Hierarchical facility location problem: Models, classifications, techniques, and applications / Reza Zanjirani Farahani, Masoud Hekmatfar, Behnam Fahimnia, Narges Kazemzadeh // Computers \& Industrial Engineering. 2014. - 68. - P. 104-117.

24. Irawan C. A. Formulation and solution of a two-stage capacitated facility location problem with multilevel capacities / C. A. Irawan, D. Jones // Ann Oper Res. - 2018. https://doi.org/10.1007/s10479-017-2741-7

25. Ус С. А. О математических моделях многоэтапных задач размещения предприятий / С. А. Ус, О. Д. Станина // Питання прикладної математики i математичного моделювання: зб.наук.пр. - 2014. - С. 258-268.

26. Us S. A. Multi-stage problem of concentration plant location/ Us S. A, Stanina O.D // 6th International Academic Conference of Young Scientists "Computer Science and Engineering 2013" (CSE-2013) / 4th International Youth Science Festival "Litteris et Artibus" November 21-23, 2013 Lviv Polytechnic National University, http://ena.lp.edu.ua:8080/handle/ntb/237

27. Киселева Е. М. Теория оптимального разбиения множеств в задачах распознавания образов, анализа и идентификации систем : монография / Е. М. Киселева, Л. С. Коряшкина, С. А. Ус // М-во образования и науки Украины, ГВНЗ "Национальный горный университет". Днепропетровск : НГУ, 2015. - 270 с.

28. Solving Continual Two Problems of Optimal Partition of Sets Stage / [D. Zelentsov, S. Us, L. Koryashkina, O. Stanina] // International Journal of Research Studies in Computer Science and Engineering (IJRSCSE). - 2017. Volume 4, Issue 4. - P. 72-80.

29. Шор Н. 3. Методы минимизации недифференцируемых функций и их приложения / Н 3. Шор. - К. : Наук. думка, 1979. - 200 с. 